\title{
HUBUNGAN ANTARA PROFITABILITAS PERUSAHAAN TERHADAP NILAI PERUSAHAAN PADA PERUSAHAAN PERKEBUNAN YANG TERDAFTAR DI BURSA EFEK INDONESIA 2014
}

\author{
Zulkifli Musannip Efendi Siregar \\ Dosen Tetap Sekolah Tinggi Ilmu Ekonomi (STIE) Labuhanbatu
}

\begin{abstract}
ABSTRAK
Penelitian ini bertujuan untuk menganalisa pengaruh profitabilitas perusahaan (Net Interest Margin) terhadap nilai perusahaan (Price Earning Ratio ) pada perusahaan perkebunan yang terdaftar di Bursa Efek Indonesia. Hipotesi dalam penelitian ini adalah Net Profit Margin berpengaruh signifikan terhadap Price Earing Ratio pada perusahaan perkebunan yang terdaftar di BEI dari tahun 2009-2012. Populasi dalam penelitian ini adalah perusahaan perkebunan yang tercatat di Bursa Efek Indonesia (BEI) dalam kurun waktu penelitian (tahun 2009- 2012).Jumlah populasi dalam penelitian ini adalah sebanyak 8 perusahaan. Teknik pengambilan sampel dilakukan melalui metode purposive sampling dengan tujuanuntuk mendapatkan sampel yang sesuai dengan tujuan penelitian. Metode purposive sampling merupakan metode pengambilan sampel yang didasarkanpada beberapa pertimbangan atau kriteria tertentu. Teknik analisis data yang digunakan adalah analisis regresi sederhana dengan menggunakan program SPSS (Statistical Package For Social Science). Hasil penelitian menunjukkan bahwa Net Profit Margin berpengaruh positif dan signifikan terhadap Price Earning Ratio dengan signifikansi 0,047. Hal ini berarti ada hubungan yang signifikan antara Net Profit Margin terhadap Price Earning Ratio pada perusahaan perkebunan yang terdaftar di Bursa Efek Indonesia. Berdasarkan hasil penelitian disarankan : 1) pada penelitian ini lingkup penelitiaan hanya pada perusahaan perkebunan yang terdaftar di Bursa Efek Indonesia, sehingga kedepan perlu di teliti lebih luas pada perusahaan perbankan yang terdaftar di luar sektor perkebunan; 2) variabel yang diteliti masih terbatas, sehingga kedepannya peneliti selanjutnya perlu menambah variabel penelitian.
\end{abstract}

Kata kunci : Net Profit Margin, Price Earning Ratio

\section{PENDAHULUAN}

Berikutakanditunjukkanperkembangannilai perusahaan, dan profitabilitas perusahaan sektor perkebunan yang terdaftar pada Bursa Efek Indonesia secaraberturutturutpada periode 2009-2012. 
Tabel 1

Data Net Profit Margin (NPM), dan Price Earning Ratio (PER)Pada Perusahaan Sektor Perkebunan 2009-2012.

\begin{tabular}{|c|c|c|c|c|c|c|c|c|c|}
\hline \multirow{2}{*}{ No } & \multirow{2}{*}{ Emiten } & \multicolumn{4}{|c|}{ NPM } & \multicolumn{4}{|c|}{ PER } \\
\hline & & 2009 & 2010 & 2011 & 2012 & 2009 & 2010 & 2011 & 2012 \\
\hline 1 & A.ALI & 22.37 & 22.80 & 23.19 & 21.22 & 21.57 & 20.46 & 13.68 & 13.90 \\
\hline 2 & BWPT & 28.67 & 34.20 & 36.07 & 29.07 & 12.54 & 21.38 & 14.13 & 18.87 \\
\hline 3 & $\mathrm{GZCO}$ & 50.11 & 35.38 & 34.08 & -2.93 & 5.63 & 13.37 & 7.89 & 14.95 \\
\hline 4 & LSIP & 22.11 & 28.76 & 44.61 & 26.65 & 16.11 & 16.97 & 7.34 & 12.32 \\
\hline 5 & SGRO & 15.52 & 19.54 & 17.49 & 10.84 & 18.11 & 31.28 & 10.23 & 18.22 \\
\hline 6 & SMLAR & 527 & 6.22 & 5.92 & 7.66 & 9.79 & 11.39 & 9.80 & 8.39 \\
\hline 7 & TBLA & 4.97 & 8.36 & 11.80 & -1.73 & 10.26 & 7.87 & 6.62 & 6.94 \\
\hline \multirow[t]{2}{*}{8} & UNSP & 10.87 & 26.81 & 1529 & 0.40 & 8.69 & 6.56 & 5.84 & 6.82 \\
\hline & $\begin{array}{c}\text { Rata- } \\
\text { rata }\end{array}$ & 19.99 & 22.76 & 23.56 & 11.40 & 12.84 & 16.16 & 9.44 & 12,55 \\
\hline
\end{tabular}

Sumber:www.idx.co.id

Berdasarkan tabel 1.1 diatas dapat diketahui bahwa tingkat perkembangan rata rata nilai perusahaan perkebunan di Bursa Efek Indonesia (BEI) selama periode 20092012 mengalami fluktuasi dan mengindikasikan nilai perusahaan yang tidak stabil. Hal ini terlihat dari nilai Price Earning Ratio (PER) pada tahun 2009, tingkat perkembangan rata-rata PER sebesar 12.84 dan mengalami kenaikan pada tahun 2010 menjadi 16.16. Pada tahun 2011 tingkat perkembangan rata-rata PER mengalami penurunan menjadi 9.44 dan kemudian mengalami kenaikan yang signifikan pada tahun 2012sebesar 12,55.

Berdasarkan data empiris, profitabilitas perusahaan juga menunjukkan angka yang tidak stabil. Hal ini terlihat dari nilai Net Profit Margin (NPM) menunjukan pada tahun 2009 sebesar 19.99. Kemudian mengalami kenaikan pada tahun 2010 menjadi sebesar22.76,setelah itu mengalami kenaikan pada tahun 2011dan tahun kembali mengalami penuruanan yang signifikan menjadi 11.40 .

Hasil penelitian terdahulu oleh Dwi Ayu ningtias (2013) menunjukkan Profitabilitas berpengaruh positif signifikan terhadap nilai perusahaan dari perusahaan perusahaan manufaktur terbuka, sehingga Hipotesis yang diajukanmendapat dukungan. Penelitian sebelumnya oleh Umi Mardiyati (2012) profitabilitas memiliki pengaruh yang positif signifikan terhadap nilai perusahaan. Hasil uji tersebut tetap sama saat model persamaanregresimenambahkanvariabelkepemilikanmanajerial.

Hal ini berarti semakin tinggi nilai profit yang di dapat maka akan semakin tinggi nilai perusahaan. Karena profit yang tinggiakan memberikan indikasi prospek perusahaan yang baik sehingga dapat memicu investor untuk ikut meningkatkan permintaan saham. Permintaan saham yang meningkatakan menyebabkan nilai perusahaan yang meningkat. 
Selanjutnya oleh Suklimah Ratih (2011) menyimpulkan bahwa pengujian pengaruh NPM terhadap NP pada perusahaan PeraihThe Indonesia Most Trusted Company-Cgpi menunjukkan koefisien path sebesar 0.155 dan tingkat signifikansi 0.512 . Hal ini berarti bahwa NPM berpengaruh positif tidak signifikan terhadap Nilai.

Berdasarkan uraian latar belakang diatas maka peneliti merasa tertarik untuk meneliti Pengaruh Net Profit Margin terhadap Nilai Perusahaan Pada Perusahaan Perkebunan Yang Terdaftar Di Bursa Efek Indonesia Periode 2009-2012”.

\section{Identifikasi Masalah}

Dari latar belakang masalah diatas maka penulis mengidentifikasi masalah penelitian ini sebagai berikut :

1. Terjadinya kenaikan dan penurunan net profit margin pada perusahaan sektor perkebunan yang terdaftar di BEI dari tahun 2009-2012

2. Terjadinya kenaikan dan penurunan Price Earning Ratio pada perusahaan perkebunanyang terdaftar di BEI dari tahun 2009-2012

3. Kenaikan dan Penurunan Net Profit Margindiikuti oleh nilai Price Earning Ratio.

\section{Rumusan Masalah}

Rumusan masalah dalam penelitian ini adalah apakah terdapat pengaruh yang signifikan antara Net Profit Margin terhadap Price Earing Ratio pada perusahaan perkebunan yang terdaftar di BEI dari tahun 2009-2012.

\section{Uraian Teoritis Nilai Perusahaan}

Harmono (2011:50) menyatakan bahwa nilai perusahaan dapat diukur melalui harga saham di pasar, berdasarkan terbentuknya harga saham di pasar, yang merupakan refleksi penilaian oleh publik terhdap kinerja perusahaan secara rill. Dikatakan secara rill karena terbentuknya harga di pasar merupakan bertemunya titik-titik kestabilan kekuatan permintaan dan titik-titik kestabilan kekuatan penawaran harga yang secara rill terjadi transakasi jual beli surat berharga di pasar modal antara para penjual (emitmen) dan para investor, atau sering disebut sebagai ekuilibrium pasar. Oleh karena itu, dalam teori keuangan pasar modal harga saham di pasar di sebut sebagai konsep nilai perusahaan.

Proses terbentuknya harga saham di pasar akan sangat tergantung pada kondisi tingkat efisiensi pasar, baik secara informal, maupun secara keputusan, mulai efisiensi bentuk lemah, setengah kuat, dan bentuk kuat.

Penilaian surat berharga saham dapat dirinci ke dalam beberapa macam jenis nilai saham, sebagai berikut :

1. Nilai nominal (par value); nilai kewajiban yang ditetapkan untuk tiap lembar saham. Kepentingannya berkaitan dengan hukum.

2. Agio saham (additional paid in capitalatau in excess of par value): selisih yang dibayar dengan nilai nominalnya.

3. Nilai modal disetor (paid in capital) : total yang dibayar oleh pemegang saham kepada emitmen untuk ditukarkan dengan saham biasa atau preferen. 
4. Laba di tahan (retained earnings): sebagai laba yang tidak dibagikan kepada pemegang saham untuk ditanamkan kembali ke perusahaan.

5. Nilai buku : menunjukkan aktiva bersih yang dimiliki pemegang saham dengan memiliki satu lembar saham. Dengan rumus :

Nilai buku per lembar $=\frac{}{\text { Jumlahsahamberedar }}$ Jumlahekuitas

6. Nilai pasar : harga yang ditentukan oleh pasar pada saat tertentu.

7. Nilai instrinsik atau nilai fundamental : nilai saham yang sebenarnya. Penentuan nilai fundamental menggunakan data keuangan perusahaan, misalnya laba, dividen, penjualan, dan sebagainya. Sedangkan analisis teknikal menggunakan data pasar.

Faktor yang mempengaruhi nilai perusahaan dapat dilihat seperti pada kerangka konsep dibawah ini :

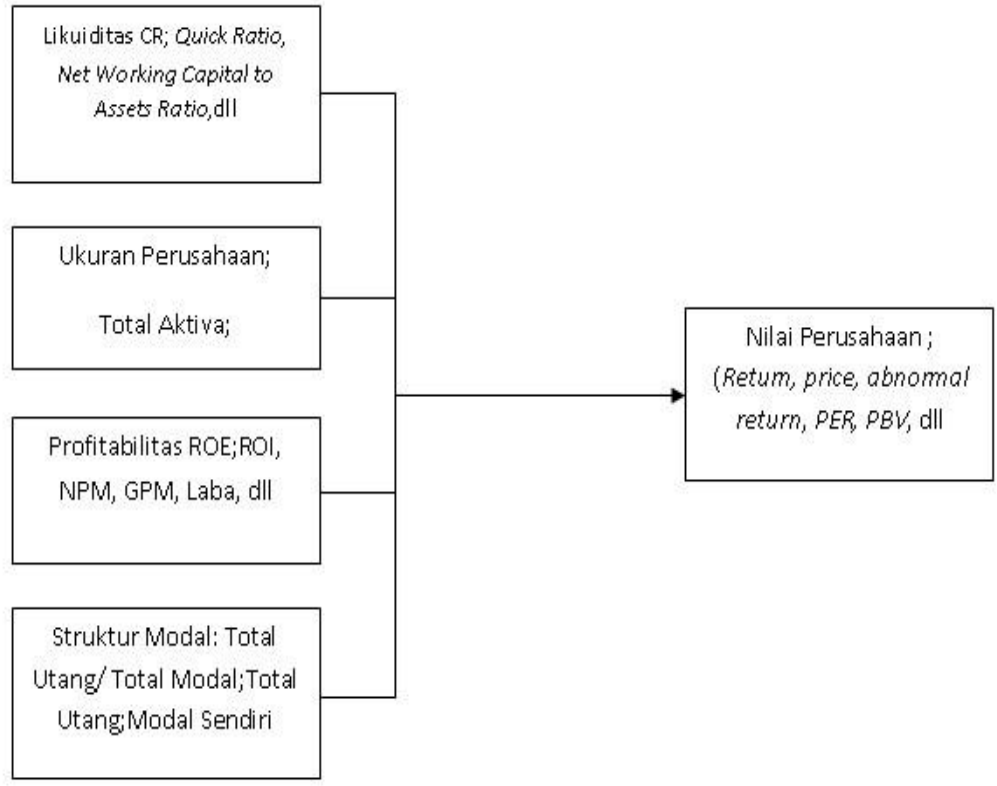

\section{Gambar 1. Kerangka Model Variabel-Variabel Kinerja Perusahaan Relevansinya Dengan Nilai Perusahaan (Harmono, 2005)}

\section{Profitabilitas perusahaan}

Menurut Harmono (2011:109) analisis profitabilitas menggambarkan kinerja fundamental perusahaan ditinjau dari tingkat efisiensi dan efektivitas operasi perusahaan dalam memperoleh laba.Binari Sinurat (1999:90) ratio profitabilitas yaitu ratio-ratio yang menunjukkan hasil akhir dari sejumlah kebijaksanaan dan keputusan-keputusan(profit margin on, retun on total asset, return on net worth dan lain sebagainya.Agus Sartono 
(2010:122) menjelaskan bahwa rasio profitabilitas adalah kemampuan perusahaan memperoleh laba dalam hubungannya dengan penjualan , total aktiva maupun modal sendiri. Dengan demikian bagi investor jangka panjang akan sangat berkepentingan dengan analisis profitabilitas ini misalnya bagi pemegang saham akan melihat keuntungan yang benar-benar akan diterima dalam bentuk dividen.

Kasmir (2012:199) menyatakan bawa dalam praktiknya rasio profitabilitas yang dapat digunakan adalah :

\section{Profit margin (Profit Margin on Sales )}

Ratio Profit Margin atau margin laba atas penjualan merupakan salah satu rasio yang digunakan untuk mengukur margin laba atas penjualan. Cara pengukuran rasio ini adalah dengan membandingkan laba bersih setelah pajak dengan penjualan bersih. Rasio ini juga dikenal dengan nama profir margin.

Terdapat dua rumus untuk mencari profit margin, yaitu sebagai berikut : Untuk margin laba kotor dengan rumus :

Profit Margin $=$ PenjualanBersi Sales

Margin laba kotor menunjukkan laba yang relatif terhadap perusahaan, dengan cara penjualan bersih dikurangi harga pokok penjualan.

Agus Sartono (2010:123) menyatakan semakin tinggi profitabilitas berarti semakin baik. Tetapi perlu diperhatikan bahwa gross profit margin sangat dipengaruhi oleh harga pokok penjualan. Apabila harga pokok penjualan meningkat maka gross profit margin akan menurun begitu pula sebaliknya. Sebagai contoh, gross profit margin sebesar 24,35\% berarti bahwa setiap Rp. 1,- penjualan mampu menghasilkan laba kotor sebesar Rp. 0,2435 .

Untuk margin laba bersih dengan rumus :

Net Profit Margin = EarningsAfterInterestandTax

Sales

Margin laba bersih merupakan ukuran keuntungan dengan membandingkan antara laba setelah bunga dan pajak dibandingkan dengan penjualan. Rasio ini menunjukkan pendapatan bersih perusahaan atas penjualan.

Agus Sartono (2010:123) menyatakan apabila gross profit margin selama suatu periode tidak berubah sedangkan net profit marginnya mengalami penurunan maka berarti bahwa biaya meningkat relatif lebih besar daripada peningkatan penjualan.

2. Return on Investmen (ROI)

Hasil pengembalian investasi atau lebih dikenal dengan nama Return On Investmen(ROI) atau return on total assets merupakan rasio yang menunjukkan hasil (return) atas jumlah aktiva yang digunakan dalam perusahaan. ROI juga merupakan suatu ukuran tentang efektifitas manajemen dalam mengelola investasinya. 
Disamping itu, hasil pengembalian investasi menunjukkan produktivitas dari seluruh dana perusahaan, baik modal pinjaman maupun modal sendiri. Semakin kecil (rendah) rasio ini, semakin kurang baik, demikian pula sebaliknya. Artinya rasio ini digunakan untuk mengukur efektivitas dari keseluruhan operasi perusahaan.

Rumus untuk mencari Return on Investmentdapat digunakan sebagai berikut :

Return on Investmen $(\mathrm{ROI})=$ EarningsAfterInterestandTax

TotalAssets

Agus Sartono (2010:123) menyatakan bahwa return on investmen atau return on assets menunjukkan kemampuan perusahaan menghasilkan laba dari aktiva yang dipergunakan. Misalnya return on investmen sebesar $5,31 \%$ berarti bahwa dengan menggunakan Rp.1000,- aktiva akan menghasilkan laba bersih sebesar Rp.53,10.

3. Return on Equity (ROE)

Hasil pengembalian ekuitas atau return on equity atau mentabilitas modal sendiri merupakan rasio untuk mengukur laba bersih sesudah pajak dengan modal sendiri. Rasio ini menunjukkan efisiensi penggunaan modal sendiri. Semakin tinggi rasio ini, semakin baik. Artinya posisi pemiliki perusahaan semakin demikian pula sebaliknya. Rumus untuk mencari Return on Equity (ROE) dapat digunakan sebagai berikut :

Return on Equity $(\mathrm{ROE})=$ EarningsAfterInterestandTax Equity

4. Laba lembar per saham (Earning per Share of Common Stock)

Rasio laba per lembar saham atau disebut juga rasio nilai buku merupakan rasio untuk mengukur keberhasilan manajemen dalam mencapai keuntungan bagi pemegang saham. Rasjin yang rendah berarti menajemen belum berhasil untuk memuaskan pemegang saham, sebaliknya dengan rasio yang tinggi, kesejahteraan pemegang saham meningkat. Dengan pengertian lain, tingkat pengembalian tinggi.

Keuntungan bagi pemegang saham adalah jumlah keuntungan setelah dipotong pajak. Keuntungan yang tersedia bagi pemegang saham biasa adalah jumlah keuntungan dikurangi pajak, dividen, dan dikurangi hak-hak lain untuk pemegang saham prioritas. Rumus untuk mencari laba per lembar saham biasa adalah sebagai berikut :

Laba Per Lembar Saham $=\frac{}{\text { SahamBiasayangberedar }}$ LabaSahamBiasa

\section{Hipotesis Penelitian}

Hipotesi dalam penelitian ini adalah Net Profit Margin berpengaruh signifikan terhadap Price Earing Ratio pada perusahaan perkebunan yang terdaftar di BEI dari tahun 2009-2012. 


\section{Metode Penelitian Jenis dan Sumber Data}

Dalam penelitian ini data yang dipergunakan adalah data sekunder berupa data Net Profit Margin dan Price Earing Ratio pada perusahaan perkebunan yang terdaftar di Bursa Efek Indonesia. Data sekunder ini diperoleh dari pengamatan dari tahun 2009 sampai 2012.

\section{Sumber Data}

Sumber data dalam penelitian ini merupakan data sekunder yang diperolehsecara historis data profitabilitas dan nilai perusahaan diambil dari laporan keuangan yang dipublikasikan pada sistus www.idx.co.id dan www.sahamok.com dari tahun 2009 s/d 2012.

\section{Populasi dan Sampel}

Populasi dalam penelitian ini adalah perusahaan perkebunan yang tercatat di Bursa Efek Indonesia (BEI) dalam kurun waktu penelitian (tahun 2009- 2012).Jumlah populasi dalam penelitian ini adalah sebanyak 8 perusahaan. Teknik pengambilan sampel dilakukan melalui metode purposive sampling dengan tujuanuntuk mendapatkan sampel yang sesuai dengan tujuan penelitian. Metode purposive sampling merupakan metode pengambilan sampel yang didasarkanpada beberapa pertimbangan atau kriteria tertentu.

\section{Teknik Analisa Data}

Adapun model regresi sederhana yang digunakan adalah sebagaimana berikut : $\mathbf{Y}=\mathbf{a}$ $+\mathbf{b X}+\mathbf{e}$

$\mathrm{Y}=$ Price Earning Ratio $\mathrm{a}=$

Konstanta $\mathrm{b}=$ Koefisien Regresi

Variabel X X = Variabel Net Profit

Margin

$\mathrm{e} \quad=$ Error Term

Kriteria pengujian hipotesis secara parsial adalah sebagai berikut :

Nilai $t_{\text {hitung }}$ akan dibandingkan dengan $t_{\text {tabel, }}$, pada tingkat segnifikasi yaitu $(\alpha)=5 \%$. Kriteria penilaian hipotesis pada uji $t$ ini adalah :

$\mathrm{H}_{0}$ diterima jika : $-\mathrm{t}_{\text {tabel }} \leq \mathrm{t}_{\text {hitung }} \leq \mathrm{t}_{\text {tabel }}$

$\mathrm{H}_{1}$ diterima jika : $\mathrm{t}_{\text {hitung }}>\mathrm{t}$ tabel

$t$ hitung $\leq-t$ tabel

\section{Pembahasan}

Berdasarkan hasil analisis regresi, hubungan antara profitabilitas perusahaan (Net Profit Margin) dengan nilai perusahaan pada perusahaan perkebunan yang terdaftar pada Bursa Efek Indonesia adalah sebagai berikut : 


\section{Coefficients $^{2}$}

\begin{tabular}{|c|c|c|c|c|c|}
\hline \multirow[b]{2}{*}{ Model } & \multicolumn{2}{|c|}{$\begin{array}{c}\text { Unstandardized } \\
\text { Coefficients }\end{array}$} & \multirow{2}{*}{$\begin{array}{c}\text { Standardized } \\
\text { Coefficients } \\
\text { Beta }\end{array}$} & \multirow[b]{2}{*}{$\mathrm{T}$} & \multirow[b]{2}{*}{ Sig. } \\
\hline & B & Std. Error & & & \\
\hline $1 \quad$ (Constant) & 11.606 & 1.873 & & 6.198 & .000 \\
\hline NPM & .059 & .080 & .133 & 2.736 & .047 \\
\hline
\end{tabular}

a. Dependent Variable: PER

Hasil penelitian menunjukkan bahwa hubungan antara Net Profit Margin berpengaruh positif dan signifikan terhadap price earning ratio dengan signifikan 0,047 . Hal ini berarti ada hubungan yang signifikan antara Net Profit Margin terhadap Price Earning Ratio pada perusahaan perkebunan yang terdaftar di Bursa Efek Indonesia. Harmono (2011:56) menyatakan terdapat dua analisis fundamental dalam menentukan nilai perusahaan yaitu pendekatan nilai sekarang dan pendekatan Price Earning Ratio(PER). PER adalah nilai harga per lembar saham, indikator ini secara praktis telah di aplikasikan dalam laporan keuangan laba rugi bagian akhir dan menjadi bentuk standar pelaporan keuangan bagi perusahaan publuik di Indonesia. Oleh karena itu, pemahaman terhadap PER penting dilakukan dan bisa dijadikan sebagai salah satu indikator nilai perusahaan dalam model penelitian. PER disebut juga sebagai pendekatan earnings multiplier, menunjukkan rasio harga saham terhadap earnings. Rasio ini menunjukkan seberapa besar investor menilai harga saham terhadap kelipatan earnings. Misalnya nilai PER sebesar 10, artinya harga saham merupakan kelipatan dari 10 kali earnings perusahaan. Jika earnings tahunan dan semua dibagikan dalam bentuk dividen, maka nilai PER 10 kali menunjukkan lama investasi pembelian saham akan kembali dalam waktu 10 tahun.

\section{Kesimpulan dan Saran Kesimpulan}

Net Profit Margin berpengaruh positif dan signifikan terhadap price earning ratio dengan signifikan 0,047. Hal ini berarti ada hubungan yang signifikan antara Net Profit Margin terhadap Price Earning Ratio pada perusahaan perkebunan yang terdaftar di Bursa Efek Indonesia.

\section{Saran}

Berdasarkan hasil penelitian dapat dikemukan beberapa saran sebagai berikut:

1. Pada penelitian ini lingkup penelitiaan hanya pada perusahaan perkebunan yang terdaftar di Bursa Efek Indonesia, sehingga kedepan perlu di teliti lebih luas pada perusahaan perbankan yang terdaftar di luar sektor perkebunan.

2. Pada penelitian ini, variabel yang diteliti masih terbatas, sehingga kedepannya peneliti selanjutnya perlu menambah variabel penelitian. 


\section{DAFTAR PUSTAKA}

Agus Sartono (2010). Manajemen Keuangan Teori dan Aplikasi. (Edisi ke 4). Yogyakarta : BPFE.

Binari Sinurat (1999). Manajemen Keungan. Jakarta : IPWI

Harmono (2011). Managemen KeuanganBerbasis Balanced Scorecard Pendekatan Toeri, Kasus dan Riset Bisnis (Edisi 1). Jakarta : Bumi Aksara.

Kasmir (2012). Analisis Laporan Keuangan. Jakarta: Raja Grafindo Persada. 